Change of characteristics of the atmospheric electrical field with height

K. Slyz'ka, (Taras Shevchenko National University of Kyiv)

\title{
SUMMARY
}

Consider an issue of changing the value and sign of the electric field with height in all latitudes and in all physical-geographical conditions. Emphasized the importance and perceptibility of such changes on the example of the existence at height of $8-12 \mathrm{~km}$ (the tropopause level) the stationary wave that leads to considerable overloads of planes. It is noted that the space charge of different polarity in the atmosphere have synoptic influence to an altitude of $20 \mathrm{~km}$, above $60 \mathrm{~km}$ the charge distribution is influenced by the energy of solar flares; charge values between these levels virtually no change over time. Layers of air with different polarization are divided levels with almost neutral environment. These levels are located at heights of approximately 2, 24, 36 and perhaps $48 \mathrm{~km}$ above ground level. Also notes the existence in magntospheric plasma in the auroral region of small-scale quasi-electrostatic structures type of double layers, "ionospheric holes", solitons, "electrostatic shocks", etc.

\section{Зміна характеристик поля атмосферної електрики з висотою}

*К.П. Слизька, (Київський наиіональний університет ім. Тараса Шевченка)

\section{PEЗЮМЕ}

Розглядається питання зміни значення і знаку електричного поля з висотою на всіх географічних широтах й у всіх фізико-географічних умовах. Наголошується на важливості та відчутності такої зміни на прикладі існування на висотах 8-12 км (рівень тропопаузи) стаціонарної хвилі, яка призводить до значних перенавантажень літаків. Зазначається, що просторові заряди різної полярності в атмосфері зазнають синоптичного впливу до висоти 20 км, вище 60 км розподіл зарядів зазнає впливу енергії сонячних спалахів, величини зарядів між цими рівнями практично не змінюються з часом. Шари повітря з різною поляризацією розділені рівнями з практично нейтральним середовищем. Дані рівні розташовані на висотах приблизно 2, 24, 36 і можливо 48 км над рівнем земної поверхні. Відмічається існування у магнітосферній плазмі в авроральній області дрібномасштабних квазі-електростатичних структур типу подвійних шарів, “іоносферних дірок”, солітонів, “електростатичних ударних хвиль" та ін. 


\section{Изменение характеристик поля атмосферной электрики с}

\section{высотой}

К.П. Слизкая, (Киевский наииональньий университет им. Тараса Шевченка)

\section{РЕЗЮМЕ}

Рассматривается вопрос изменения значения и знака электрического поля с высотой на всех географических широтах и во всех физико-географических условиях. Отмечается важность и осязаемости такого изменения на примере существования на высотах 8-12км ( уровень тропопаузы ) стационарной волны, которая приводит к значительным перегрузкам самолетов. Отмечается, что пространственные заряды разной полярности в атмосфере подвергаются синоптической влияния до высоты 20 км, выше 60 км распределение зарядов подвергается воздействию энергии солнечных вспышек, величины зарядов между этими уровнями практически не меняются со временем. Слои воздуха с разной поляризацией разделены уровнями с практически нейтральной средой. Данные уровни расположены на высотах примерно 2, 24, 36 и возможно 48 км над уровнем земной поверхности. Отмечается существование в магнитосферной плазмы в авроральной области мелкомасштабных квазиэлектростатических структур типа двойных слоев, "ионосферных дыр", солитонов, "электростатических ударных волн" и др. 
Характеристики електричного поля атмосфери є предметом підвищеної зацікавленості в науковому світі. Тільки питання фізики процесу утворення та існування блискавки (лінійної та кульової) вивчається протягом століть, але жоден дослідник не розкрив всіх секретів даного природного явища.

До цього часу також достеменно не відома причина зміни значення і знаку електричного поля 3 висотою на всіх географічних широтах й у всіх фізико-географічних умовах, хоча така зміна достатньо відчутна. Наприклад, існування на висотах 8-12км стаціонарної хвилі (рівень тропопаузи) призводить до значних перенавантажень літаків. Ще у працях Фіцроя (1860-ті роки) йшлося про електричну неоднорідність атмосфери. Зокрема він відмічав, що полярне повітря наелектризоване позитивно, а тропічне-негативно.

Просторові заряди різної полярності в атмосфері зазнають синоптичного впливу до висоти 20км, вище 60км розподіл зарядів зазнає впливу енергії сонячних спалахів, величини зарядів між цими рівнями практично не змінюються з часом. Концентрація іонів різко зменшується нижче 90км, досягаючи мінімуму близько $10^{8} \mathrm{ioн} / \mathrm{m}^{3}$ на висоті 70-80км, але при цьому спостерігається чітко виражений локальний мінімум на 85км. Шари повітря 3 різною поляризацією (за даними досліджень Ю.А. Брагіна) розділені рівнями 3 практично нейтральним середовищем. Переважна ж більшість дослідників вважає, що зміна знаку просторового заряду в атмосфері $\epsilon$ неможливою і дана зміна $\epsilon$ результатом неточності вимірювальної апаратури.

Існують дослідження, які підтверджують, що на висотах 180-330км інтенсивність електронів радіаційних поясів значно перевищує космічний фон, в точках, які пов'язані з частинами Землі, які знаходяться на поверхні чи лежать нижче 50км вглиб: в північній півкулі - в районі Південно-Атлантичної відємної геомагнітної аномалії, а в південній півкулі - в районі аномалії з центром в межах Беренгового моря.

Супутникові дослідження показали, що в області протікання повздовжних струмів спостерігається подібність профілів електричного і магнітного полів. Це явище спостерігається в будь-якому секторі авроральної іоносфери, навіть в період збурень. А замикання повздовжних струмів поперечними призводить до виникнення великих стрибків значень електричного поля. Також стало відомо про існування у магнітосферній плазмі в авроральній області дрібномасштабних квазі-електростатичних структур типу подвійних шарів, “оносферних дірок', солітонів, “електростатичних ударних хвиль' та ін. Для них характерна наявність пари протилежно направлених електростатичних полів, орієнтованих ортогонально магнітному полі. Вони зазвичай також вміщують в собі області повздовжнього електричного поля, і у випадку несиметричності пари додатного і відємного потенціалів вздовж магнітного поля в цих областях відбувається прискорення заряджених часточок та формування авроральних пучків. Подвійні шари неодноразово розглядалися як одна 3 можливостей прискорення часток, що призводять до утворення полярних сяйв.

Дослідження причин зміни характеристик електричного поля в атмосфері 3 висотою, вважаючи, що наявні на даний момент вимірювання просторового заряду атмосфери $\epsilon$ правдивими і точними, є метою даної роботи. Основним результатом дослідження буде встановлення зв’язку електромагнітного поля атмосфери з електромагнітним полем Землі.

\section{Посилання}

1. Аллик Р.А. Электрическое состояние атмосферы и воздушные массы // Труды ГГО, 1937, вып. 20, с. 5 - 34.

2. Брагин Ю.А., Шамахов Б.Ф. Прямые исследования знака пространственного заряда атмосферы ниже 50км // Космические исследования, 1969, том 7, №5, с. 741-746.

3. Брагин Ю.А., Тютин Олександр А., Кочеев А.А., Тютин Алексей А. Прямые измерения напряженности вертикального электрического поля атмосферы до 80км // Космические исследования, 1974, том 12, №2, с. 306-308.

4. Вернов С.Н., Савенко И.А., Тверская Л.В., Тверской Б.А., Маврин П.И. Об особенности электронов радиационных поясов на высотах 180 - 330км в районах, сопряженных с отрицательными геомагнитными аномалиями // Космические исследования, 1965, том. 3, №1, c. 128-134. 
5. Волосевич А.В., Гальперин Ю.И. Нелинейные квазистационарные электростатические структуры в магнитосфере плазмы // Космические исследования, 1995, том 33, №1, с. 5261.

6. Николаева Н.С., Дубинин Э.М., Израйлевич П.Л., Подгорный И.М. Связь между электрическим полем и продольными токами по данным спутника“Интеркосмос-Болгария 1300'// Космические исследования, 1988, том 16, №3, 463-468.

7. Смирных Л.Н. Ракетные измерения концентрации положительных ионов ниже 90км // Космические исследования, 1976, том 14, №1, с. 151-152.

8. Шалимов С.Л. Замыкание продольных токов поперечными токами и сильные электростатические скачки в полярной верхней ионосфере // Космические исследования, 1997, том 35, №2, с. 139-143. 